\title{
SEXUAL ASSAULT IN A PREMENACHAL GIRL COMPLICATED BY FOURTH DEGREE PERINEAL TEAR: A CASE REPORT
}

)$^{0}$ Nasir S, ${ }^{2}$ Adoke A.U 'National Obstetric Fistula Centre, Babbar-Ruga, Katsina, Nigeria. ${ }^{2}$ Usmanu Danfodiyo University Teaching Hospital Sokoto, Nigeria

*Corresponding author: Dr. Sadiya Nasir, National Obstetric Fistula Centre, Babbar-Ruga, Katsina, Nigeria sadiyanasir@gmail.com GSM: +2348036895834

\section{Abstract}

Sexual assault is a crime against humanity. Majority of cases are sunk into total oblivion with few reported cases. Among the reported cases, many are also covered up due to the stigma and socio-cultural issues associated. Therefore, because no one is held accountable for his actions the menace of sexual assault is a recurring decimal in our society and community as a whole. We present a case of 9 year old that was drugged, sexually assaulted by a close family relation in which she sustained severe psychological, mental and genital injury.

Key words: Sexual assault, Premenachal Girl, Fourth degree, Perineal, tear

\section{INTRODUCTION}

$\mathrm{S}_{\mathrm{c}}^{\mathrm{c}}$ exual assault is a spectrum of acts, including coerced sex in marriage and dating relationships, rape by strangers, organized rape in war, sexual harassment (including demands of sex for jobs or school grades), and rape of a child, trafficking of women and girls, female genital mutilation, and forced exposure to pornography., It is a severely traumatic experience that disproportionally affects women and girls. ${ }^{2}$ It is often associated with psychological, physical, social distress and occasionally result in fatality either from shock, severe injury or murder by the perpetrator in an attempt to conceal his identity.

Sexual assault is a pandemic crime against humanity that is underreported, particularly in the low resource countries ${ }^{3}$, because of the enduring culture of male dominance, female social and economic disempowerment and poor or nonprosecution of sex offenders. ${ }^{3,4}$ The World Health Organization(WHO) reports, 1 in every 5 women is a victim of sexual assault ${ }^{5}$ and globally, $35 \%$ of women have experienced either physical and/or sexual intimate partner violence or non-partner sexual violence. ${ }^{6}$ The reported figures are said to be inaccurate and often underestimated as most cases of sexual assault are under-reported by the victims because of the associated stigma. ${ }^{7}$ In Nigeria, only 2 of 40 cases of rape are reported, attributing this amongst other reasons, to the arduous legal requirements needed to prove the cases and the associated stigma. ${ }^{1,8}$ The reported incidence of sexual assault in Nigeria ranged from $13.8 \%$ among female students in Maiduguri ${ }^{7}$ to $15 \%$ among young females in Ibadan'. Until 2002, the management of sexual assault especially prevention was a major challenge in our setting., The introduction of the Federal Government of Nigeria antiretroviral drug access programme in 2002 changed this poor out look as, a number of post exposure prophylaxis programmes were established across the country. Public health education and campaign on the need for persons occupationally and non-occupationally exposed to HIV and other infectious agents to avail themselves of these services in other to avert infection were intensified. It is hoped that a lot more persons sexually assaulted will avail themselves of this preventive service even if they do not want to report to the police. This will hopefully assist in narrowing the gaps in the reported cases of sexual assault in Nigeria and worldwide. The objective of this case report is to create awareness of sexual assault involving young children in our society with a view to prompt recognition and management of the condition and its resultant complication(s).

\section{Case Presentation}

Miss H.Y is a 9-year-old premenarchal girl referred from General Hospital Funtua, Katsina State, on 
account of 11 days history of passage of stool per vaginam with associated flatus incontinence following sexual assault. The leakage of stool was noticed a day after she was assaulted by her paternal uncle who drugged her and dumped her in the bush after the assault. She was rescued and taken to the referral hospital where she was admitted for about a week before subsequent referral to our hospital accompanied by a police officer.

There was no history of leakage of urine or other systemic involvement.

Examination findings revealed a young girl looking apprehensive with no gait abnormality. She was not pale, anicteric, acyanosed and well hydrated. She weighed $23 \mathrm{~kg}$ and her height was $1.2 \mathrm{~m}$. Her BMI was $16 \mathrm{~kg} / \mathrm{m}^{2}$, which was underweight.

There were no abnormal findings in the respiratory system. Her pulse rate was 98 beats per minute. Her blood pressure was $100 / 60 \mathrm{mmHg}$. Heart sounds were normal. There was no significant finding on abdominal examination.

Pelvic examination revealed an infantile vulva, smeared with faeces. There was a deep laceration involving the posterior vaginal wall, perineum, sphincters and the rectum. The hymen was absent. The urethra and the anterior vaginal wall were normal.

A diagnosis of traumatic fourth degree perineal tear secondary to sexual assault was made. She was counseled together with her parents by the social welfare unit before she was subsequently planned for examination under anaesthesia and repair.

The investigation findings were packed cell volume of $35 \%$,

$\begin{array}{ll}\text { Urine } \mathrm{M} / \mathrm{C} / \mathrm{S} \text { - } & \text { Normal } \\ \text { Urinalysis - } & \text { Normal }\end{array}$

Retroviral screening - Non reactive

$\mathrm{E} / \mathrm{U} / \mathrm{Cr}$ - Normal

Wound swab M/C/S - No growth after 24 hours of incubation

Examination under anaesthesia revealed an infantile vulva with absent hymen. There was no active bleeding. There was a clean laceration of about $4 \mathrm{~cm}$ long involving the posterior vaginal, perineum, sphincters and the rectal mucosa with no evidence of wound infection. She subsequently had repair of the anorectum, sphincter, and perineal body reconstruction. Post operatively she was placed on antibiotics, analgesics and high fibre diet for five days and liquid paraffin for 10 days. Her urethral catheter was removed on the $5^{\text {th }}$ postoperative day.

She had steady recovery with no flatus or stool incontinence. She was discharged home two weeks after surgery to be seen in the clinic after four weeks.

At follow up, she had no complaint and is now continent of flatus and stool.

Images: I-(Pre-operative), II (After repair), III- (At discharge)

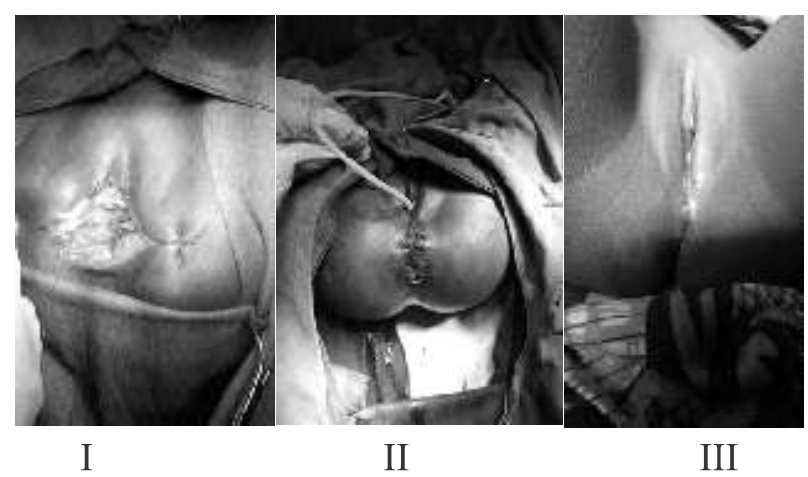

\section{DISCUSSION}

Sexual assault is a severely traumatic experience that may be complicated by serious psychological, mental and genital injuries. In some instances life threatening injuries and even death have being recorded. ${ }^{2,3}$ In this case she was drugged, assaulted and dumped at a site outskirt of the town. This is typically observed in most cases of assault due to close family relation and it was amazing but rather disturbing that her uncle could commit such a heinous crime. Studies have shown that the assailant is known to the victim and this case was not an exception. ${ }^{10,11}$ However the index case was so lucky that she was rescued immediately after the gory incidence of rape hence mortality was avoided. 
The WHO finding of 1 in 5 women being raped and $35 \%$ of women having experienced rape is an alarming finding. ${ }^{5,6}$ Despite the rising incidence of sexual assault, it is an underreported menace that need to be tackled head-on. The reason for under reporting is the fear of stigmatization and punishment by the assailant. Hence there is limited information on the subject in our environment with most cases swept under the carpet. Again this case took a similar dimension just like all other cases, the family intervened and the case died a natural death as it was covered up. Until the law takes its course on the assailants we will continue to live in fear of who the next victim will be.

Sexual assault is commoner among teenagers and unmarried women with more cases among minors being reported. In war torn countries, minors are far more vulnerable because they have lost parental protection. Such parents or guardians may have died or been maimed as a result of war. In this case she was staying in her uncle's house and he has being the one taking care of her.

Varying degree of injuries have being sustained following sexual assault, with most cases having genital injuries. The degree of genital injury ranges from mild first degree vaginal injury to severe form which is fourth degree. Mbachu et al ${ }^{11}$ reported a case of third degree perineal tear resulting from sexual assault on a 7 year old girl. Our patient had $4^{\text {th }}$ degree vaginal tear which was repaired with satisfactory outcome. The timing of vaginal repair was immediate in this case because the wound was healthy and the edges were clean with no tissue loss.

\section{CONCLUSION}

Child sexual assault may be life threatening and associated with severe genital injury. Psychological support and repair of genital injury will help to improve outcome.

\section{REFERENCES}

1. Akinlusi FM, Rabiu KA, Olawepo TA, Adewunmi AA, Ottun TA, Akinola OI. Sexual assault in Lagos, Nigeria: a five-year retrospective review. Accessed on March 102016.

2. Haile RT, Kebeta ND, Kassie GM: Prevalence of sexual abuse of male high school students in Addis Ababa, Ethiopia. Accessed on March 102016.

3. Badejoko OO, Anyabolu HC, Badejoko BO, Ijarotimi AO, Kuti O, Adejuyigbe EA. Sexual assault in Ile-Ife, Nigeria. Niger Med J. 2014;55:254-9

4. Akinade E, Adewuyi T, Sulaiman A. Socio-legal factors that influence the perpetuation of rape in Nigeria. Procedia - social and behavioral sciences. 2010; 5:1760-4.

5. Garcia-Moreno C, Watts C. Violence against women: an urgent public health priority. Bulletin of the World Health Organization. 2011; 89:2-2.

6. World Health Organization: Global and regional estimates of violence against women: prevalence and health effects of intimate partner violence and nonpartner sexual violence. World Health Organization; $2013 ; 2$.

7. Kullima AA, Kawuwa MB Audu BM, Mairiga AG, Bukar M. Sexual Assault against Female Nigerian Students. Afr J Reprod Health. 2010; 14(3):189-93.

8. Akhiwu W, Umanah IN, Olueddo AN. Sexual Assaults in Benin City, Nigeria. TAF Prev Med Bull. 2013; 12(4): 377-82.

9. Ajuwon A. Attitudes, norms and experiences of sexual coercion among young people in Ibadan, Nigeria: sex without Consent: Young people in Developing Countries. London and New York, Zed Books. 2005; 96-104.

10. Oliver Chukwujekwu Ezechi et al. Trends and Pattern of sexual assault in Lagos South western NigeriaThe Pan African Medical Journal. 2016; 24:261

11. Mbachu II, Obiechina NJA, Umeononihu OS, Ezebialu IU, Akabuike JC, Umeobika JC. Third Degree Perineal Tear Following Sexual assault in a minor: a case report and review of literature Afrimedic Journal 2010; 1(1): 37-38. 